Jurnal Sistim Informasi dan Teknologi
https://jsisfotek.org/index .php

\title{
Sistem Pakar dalam Membandingkan Metode Forward Chaining dengan Certainty Factor untuk Mengidentifikasi Jenis Kulit Wajah
}

\author{
Nadya Alinda Rahmi ${ }^{1 凶}$, Gunadi Widi Nurcahyo ${ }^{2}$ \\ ${ }^{1}$ Independent Researcher \\ ${ }^{2}$ Universitas Putra Indoensia YPTK Padang \\ nadyaa1indaarr@gmai1.com
}

\begin{abstract}
Skin is one piece of the body that has adaptable properties to shield the human body from natural effects. A great many people need facial skin that is tight and liberated from skin illnesses, particularly skin inflammation inclined skin. Next, everybody ought to do facial consideration and utilize a few fixings that are appropriate for facial skin, there are five kinds of ordinary skin, sleek skin, dry skin, blend skin and touchy skin. To inspect the kind of facial skin by contrasting the Forward Chaining and Certainty Factor procedures. This assessment utilizes 30 information acquired from interviews with subject matter experts. There are a few signs acquired from different issues distinguished on facial skin which are utilized as indication data for facial skin types constrained by subject matter experts. This data is utilized to check the sort of facial skin dependent on guidelines and data from a trained professional. The preliminary advances taken are to look at the Forward Chaining and Certainty Factor strategies. The outcomes acquired subsequent to testing and assessment of the Forward Chaining and Certainty Factor strategies were $83.33 \%$ and the discoveries expressed that the customer had a commonplace skin type. The test outcomes can be seen from the two strategies that test unequivocal facial skin types, then, at that point the principle system utilized not set in stone to help dermatologists in analyzing facial skin types.
\end{abstract}

Keywords: Expert System, Facial Skin Type, Certainty Factor Method, Forward Chaining Method, Face Treatment.

\begin{abstract}
Abstrak
Kulit merupakan salah satu bagian tubuh yang memiliki sifat fleksibel untuk melindungi tubuh manusia dari dampak ekologis. Sebagian besar orang membutuhkan kulit wajah yang kencang dan terbebas dari penyakit kulit, terutama kulit berjerawat. Oleh karena itu, setiap orang harus melakukan perawatan wajah dan menggunakan beberapa bahan yang cocok untuk kulit wajah, ada lima jenis kulit normal, kulit berminyak, kulit kuring, kulit kombinasi dan kulit sensitif. Untuk mengkaji jenis kulit wajah dengan membandingkan teknik Forward Chaining dan Certainty Factor. Pemeriksaan ini menggunakan 30 data yang diperoleh dari wawancara dengan spesialis. Ada beberapa indikasi yang diperoleh dari berbagai masalah yang diidentifikasi pada kulit wajah yang digunakan sebagai informasi manifestasi untuk jenis kulit wajah yang dikendalikan oleh spesialis. Informasi tersebut digunakan untuk memeriksa jenis kulit wajah berdasarkan petunjuk dan informasi dari dokter spesialis. Langkah-langkah persiapan yang dilakukan adalah dengan membandingkan teknik Forward Chaining dan Certainty Factor. Hasil yang didapat setelah pengujian dan pemeriksaan teknik Forward Chaining dan Certainty Factor adalah 83,33\% dan hasil temuan menyatakan bahwa klien memiliki jenis kulit yang khas. Hasil pengujian dapat dilihat dari dua teknik yang menguji jenis kulit wajah eksplisit, selanjutnya kerangka utama yang digunakan dapat ditentukan untuk membantu dokter kulit dalam membedah jenis kulit wajah.
\end{abstract}

Kata kunci: Sistem Pakar, Jenis Kulit Wajah, Certainty Factor, Forward Chaining, Perawatan Wajah.

(C) 2021 JSisfotek

\section{Pendahuluan}

Teknologi komputer yang berkembang saat ini, menarik perhatian semua kalangan karena sangat membantu dalam kehidupan sehari-hari. Perkembangan teknologi ini memungkinkan teknologi memiliki kecerdasan serangan manusia yang disebut kecerdasan buatan atau lebih dikenal dengan AI (Artificial Intelligence). Kecerdasan buatan atau Artificial Intelligence adalah kecerdasan yang ditanamkan dalam suatu sistem untuk memecahkan masalah kognitif yang kompleks [1]. Sistem Pakar adalah suatu sistem yang terdapat dalam pengetahuan manusia ke dalam suatu sistem, bukan sebuah komputer dimana sistem ini dapat meniru berarti Sistem Pakar akan menggantikan peran seorang proses penalaran seorang pakar yang memiliki pakar, tetapi Sistem Pakar digunakan untuk membantu pengetahuan dalam memecahkan suatu masalah dimana

masalah tersebut memerlukan pemikiran seorang pakar [2]. Sistem Pakar adalah cabang dari kecerdasan buatan terapan, yang digunakan untuk mengambil pandangan ahli tanpa adanya keahlian manusia. Karena tidak adanya ahli di bidang tertentu, FES akan memecahkan masalah dunia nyata yang kompleks [3]. Sistem Pakar disajikan yang melakukan tindakan pemodelan untuk memulihkan situasi masalah dan memperbaiki berbagai jenis kesalahan, kegagalan berbagai sistem, dan menentukan penghapusan malfungsi sistem transportasi kereta api otomatis dan telemekanis [4]. Walaupun Sistem Pakar dibangun dengan memasukkan berarti Sistem Pakar akan menggantikan peran seorang
pakar, tetapi Sistem Pakar digunakan untuk membantu Diterima: 01-09-2021 | Revisi: 01-10-2021 | Diterbitkan: 31-12-2021 | DOI: 10.37034/jsisfotek.v3i4.756 
masyarakat umum menemukan cara untuk dengan diagnosa sistem (system akurasi testing) yang memecahkan masalah yang sedang dialami [5].

artinya Sistem Pakar dengan menggunakan metode Forward Chaining dan Certainty Factor layak untuk

Pada penelitian sebelumnya, Sistem Pakar digunakan untuk mendiagnosis vertigo. Penyakit vertigo inilah digunakan [9].

yang menyebabkan gangguan keseimbangan yang Peneliti lain sebelumnya yang mengimplementasikan biasanya disebut dengan pusing, terhuyung-huyung, Sistem Pakar dirancang untuk kemampuan dokter rasa melayang, badan atau bumi berputar bahkan dalam mendeteksi dan mendiagnosis gejala virus jungkir balik. Meskipun teknologi sekarang Corona, gejala umum penyakit ini adalah demam, berkembang pesat, masih sulit untuk mendiagnosis batuk, radang paru-paru dan sesak napas. Sistem ini vertigo. Maka pada penelitian ini digunakan metode menyajikan gejala penyakit, hari di mana gejala akan Dempster Shafer untuk mendiagnosis vertigo. Hasil dikenali, kelangsungan hidup dan penyebaran, kondisi penelitian adalah berhasil dibangunnya prototipe yang menguntungkan dan deskripsi gejala ini. Sistem Sistem Pakar diagnosis vertigo yang dapat Pakar Delphi digunakan untuk merancang dan menampilkan gejala dan diagnosis vertigo serta mengimplementasikan Sistem Pakar yang diusulkan. menunjukkan cara penanganannya [6].

Sistem Pakar tidak hanya terbatas pada bidang medis saja, tetapi juga dapat diterapkan pada penelitian di luar bidang medis seperti penelitian-penelitian sebelumnya yang menggunakan Sistem Pakar untuk mendiagnosa kerusakan pada gitar. Gitar yang merupakan bagian dari alat musik seringkali mengalami kerusakan namun dianggap sepele. Kerusakan pada gitar akan berdampak Penerapan Sistem Pakar dengan menggunakan metode pada kualitas suara, oleh karena itu diperlukan Certainty Factor dan Forward Chaining cukup banyak pemahaman dalam menangani kerusakan gitar. Sistem digunakan dalam menyelesaikan banyak permasalahan Pakar ini menggunakan metode Certainty Factor dan di berbagai bidang kehidupan. Salah satunya adalah metode Forward Chaining untuk mendiagnosa permasalahan di bidang kecantikan seperti Sistem kerusakan pada gitar. Hasil yang diperoleh dari Pakar menggunakan metode Certainty Factor untuk penelitian ini adalah sebuah sistem yang dapat estetika kulit wanita dalam menjaga kesehatan. Hasil menjawab kerusakan yang dialami gitar dengan pengujian metode Certainty Factor sebanyak 13 data menjawab aturan yang dipilih, dan juga lengkap dengan penyakit estetika kulit teridentifikasi 15 data uji coba persentase tingkat kepastian dari kerusakan gitar [7]. dengan tingkat akurasi 86,67\% [11].

Penelitian sebelumnya juga menerapkan Sistem Pakar, Kulit merupakan bagian terpenting dari tubuh manusia, yaitu semua Sistem Pakar ini dikembangkan untuk terutama wanita. Kulit juga membentuk $15 \%$ dari berat menyelesaikan masalah tanpa mempertimbangkan badan manusia. Pada permukaan kulit terdapat porisemua kemampuan pesawat. Dalam jurnal ini, Sistem pori yang menjadi tempat keluarnya keringat di mana Pakar Material Pesawat (AMES) tentang kemampuan cairan keringat yang keluar membuat tubuh lebih sehat. dan tata letak pesawat dikembangkan berdasarkan Kulit memiliki beberapa fungsi diantaranya sebagai pengetahuan banyak pakar dan data penerbangan. pelindung pertama tubuh, sebagai indera perasa dan Sistem pendukung keputusan (DSS) dirancang, dan juga sebagai alat komunikasi, serta pengatur suhu tubuh alurnya dimodelkan oleh Sistem Pakar untuk pemilihan manusia [12].

material pesawat [8].

Ada berbagai cara untuk menemukan jawaban atas Penelitian sebelumnya juga telah menerapkan Sistem masalah kulit wajah, salah satunya dengan Pakar untuk hewan seperti Sistem Pakar untuk memeriksakan diri ke dokter kecantikan atau klinik mendiagnosa penyakit pada kambing menggunakan kecantikan. Namun ada beberapa permasalahan yang metode Forward Chaining dan Certainty Factor. dihadapi yaitu jumlah tenaga ahli kecantikan kulit yang Penyakit pada kambing secara umum dikenal dua jenis relatif sedikit, biaya pengobatan yang mahal, dan yaitu penyakit menular dan penyakit tidak menular, aktivitas masyarakat yang padat sehingga tidak dapat untuk mencegah penyakit kambing menular diperlukan memeriksakan diri ke dokter. Berdasarkan keseluruhan suatu sistem yang dapat mendiagnosa penyakit penjelasan yang dikemukakan diatas, maka penulis kambing, dimana terdapat 14 jenis penyakit kambing perlu melakukan penelitian dengan judul yaitu Sistem yang akan didiagnosa. Hasil penelitian ini diuji dengan Pakar Membandingkan Metode Forward Chaining empat pengujian yaitu pengujian blackbox, pengujian dengan Faktor Kepastian Identifikasi Jenis Kulit kuesioner, pengujian teoritis dan pengujian akurasi Wajah.

sistem. Dimana hasil yang didapat untuk pengujian blackbox rata-rata sebesar $85 \%$, untuk pengujian 4 kuesioner mendapatkan hasil sebesar 4,35 dari skala 5, dan untuk pengujian teoritis hasil perhitungannya sama

Jurnal Sistem Informasi dan Teknologi Vol. 3 No. 4 (2021) 257-262 


\section{Metodologi Penelitian}

\subsection{Subjek Penelitian}

Dalam penelitian ini subjek menggunakan Sistem Pakar untuk mengidentifikasi jenis kulit wajah dengan membandingkan Forward Chaining dan Certainty Factor sebagai dua metode yang digunakan. Permasalahan dalam penelitian ini adalah kurangnya tenaga ahli terkait kecantikan, selain itu mahalnya biaya untuk melakukan perawatan kulit menjadi alasan untuk tidak melakukan perawatan wajah padahal dapat merusak kulit nantinya.

\subsection{Sistem Pakar}

Sistem Pakar merupakan bagian dari Kecerdasan Buatan yang berawal dari pemikiran seorang pakar yang kemudian menjadi teknologi buatan. Sistem Pakar (Expert System) adalah suatu sistem yang berusaha menerapkan pengetahuan manusia ke dalam komputer agar dapat memecahkan masalah seperti para ahli [13].

\subsection{Metode Forward Chaining}

Forward Chaining adalah teknik untuk mencari informasi berupa kesimpulan yang diturunkan dari fakta - fakta yang telah diperoleh dengan kumpulan fakta - fakta tersebut. Jika fakta cocok dengan bagian IF, maka aturan dapat dieksekusi. Jika aturan sudah berlaku, maka fakta baru ditambahkan ke basis data. Aturan dimulai dari atas dan setiap aturan hanya dapat dijalankan sekali [14].

\subsection{Metode Certainty Factor}

Certainty Factor adalah faktor kepastian untuk membuktikan ketidakpercayaan pemikiran ahli, di mana dalam menggambarkan tingkat kepercayaan ahli memerlukan faktor kepastian, biasanya hasil metode faktor kepastian berupa persentasi [15].

Perhitungan data yang memanfaatkan metode Certainty Factor harus memiliki tabel uncertainty term yang dibutuhkan dalam menginterpretasikan term seorang pakar ke dalam nilai NA, dimana tabel uncertainty term disajikan pada Tabel 1.

Tabel 1. Tabel Uncertainty Term

\begin{tabular}{clc}
\hline No & Uncertainty Term & Nilai CF \\
\hline 1. & Pasti Tidak & 0 \\
2. & Tidak Yakin & 0.2 \\
3. & Sedikit Yakin & 0.4 \\
4. & Cukup Yakin & 0.6 \\
5. & Yakin & 0.8 \\
6. & Sangat Yakin & 1.0 \\
\hline
\end{tabular}

Rumus yang paling sering dipergunakan dalam perhitungan metode Certainty Factor disajikan pada Rumus 1:

$N A=N A\left(U_{s e r}\right) \times N A($ Pakar $)$

Dimana NA merupakan nilai Certainty Factor, $\mathrm{NA}($ User $)$ adalah nilai dari beberapa gejala yang dipilih oleh User dan NA(Pakar) merupakan nilai fakta yang didapatkan dari seorang pakar.

Jika pada saat melakukan perhitungan terdapat beberapa gejala yang memiliki fakta yang sama maka pada proses perhitungan Certainty Factor digunakan rumus yang disajikan pada Rumus 2:

$$
N A_{\text {combine }}=N A_{1}+N A_{2} \times\left(1-N A_{1}\right)
$$

Dimana $\mathrm{NA}_{\text {combine }}$ adalah nilai dari perhitungan Certianty Factor yang memiliki beberapa fakta yang sama, $\mathrm{NA}_{1}$ adalah nilai Certainty Factor pada fakta pertama dan $\mathrm{NA}_{2}$ adalah nilai Certaint Factor pada fakta kedua

\subsection{Metode Pengumpulan Data}

Pengumpulan data dilakukan dalam mengarahkan penjelajahan ini dengan menggunakan dua strategi, yaitu studi penulisan khusus (buku-buku pemahaman dan referensi lain) yang diidentifikasi dengan penelitian dan melakukan pertemuan dengan para ahli penting pada objek penelitian. Pertemuan-pertemuan dilakukan merupakan pertemuan-pertemuan langsung pada tempat praktek ahli dari objek penelitian.

\subsection{Kerangka Kerja}

Kerangka kerja dibutuhkan pada saat melakukan suatu penelitian dimana kerangka kerja berfungsi untuk dapat menyelesaikan setiap langkah dari penelitian dengan kualitas yang diinginkan. Kerangka kerja yang digunakan dalam penelitian ini dapat dilihat pada Gambar 1.

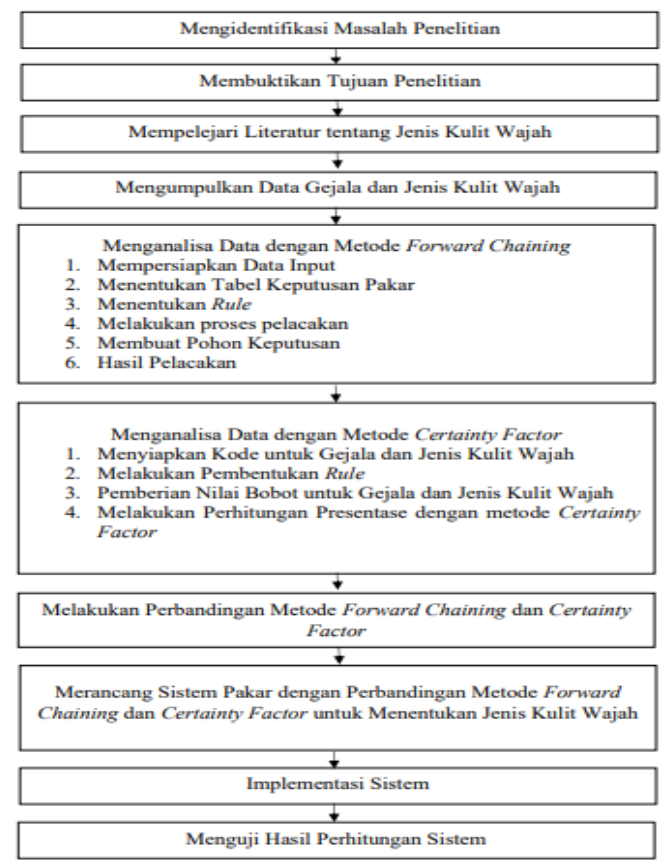

Gambar 1. Kerangka Kerja

Kerangka kerja disebut juga gambaran detail dari setiap langkah penelitian yang teroganisir yang dimanfaatkan untuk mencapai tujuan dan memperoleh kualitas yang diinginkan. 


\section{Hasil dan Pembahasan}

\subsection{Analisis Data}

Data yang digunakan dalam melakukan penelitian ini disajikan pada Tabel 3 diberikan kode dimulai dari A01 antaralain data jenis kulit wajah dan data gejala sampai A31. Selanjutnya dilakukan pembuatan rule dan penyakit, dimana kedua jenis data ini nantinya nilai NA yang telah didapatkan dari pakar yang digunakan dalam melaksanakan pengujian sistem. Data disajikan pada Tabel 4.

tersebut diperoleh dari wawancara lansung dengan seorang pakar yang disjaikan pada Tabel 2.

Tabel 2. Jenis Kulit Wajah

\begin{tabular}{ccl}
\hline No & Kode Penyakit & Nama Penyakit \\
\hline 1. & K1 & Kulit Normal \\
2. & K2 & Kulit Berminyak \\
3. & K3 & Kulit Kering \\
4. & K4 & Kulit Kombinasi \\
5. & K5 & Kulit Sensitif \\
\hline
\end{tabular}

Diperoleh 5 jenis kulit wajah, dimana setiap jenis kulit wajah diberikan kode yang dimulai dari K1 sampai Terdapat 5 rule yang diimplemntasikan pada proses dengan K5 yang telah disajikan pada Tabel 2. Setelah perhitungan Certainty Factor dengan memanfaatkan data jenis kulit wajah data yang telah diterima dari nilai pakar yang telah diperoleh. Perhitungan terhadap pakar merupakan data gejala penyakit yang disajikan pasien disajikan pada Tabel 5. pada Tabel 3 .

Tabel 3. Data Gejala Penyakit

\begin{tabular}{ccl}
\hline No & Kode & Gejala \\
\hline 1. & A01 & Kulit wajah tidak berminyak \\
2. & A02 & Tekstur wajah terlihat halus \\
3. & A03 & Makeup mudah menempel di wajah ketika digunakan \\
4. & A04 & Kulit sehat \\
5. & A05 & Tidak ada jerawat di wajah \\
6. & A06 & Sederhana untuk memilih kosmetik \\
7. & A07 & Pori-pori besar di wilayah T-Zone \\
8. & A08 & Kulit tampak mengkilat \\
9. & A09 & Sering timbul jerawat \\
10. & A10 & Adanya permasalahan whitehead (komedo putih) \\
11. & A11 & Pori- pori di wajah kecil \\
12. & A12 & Memiliki permukaan wajah yang tipis \\
13. & A13 & Sering muncul kerutan \\
14. & A14 & Sebagian wajah berminyak \\
15. & A15 & Sebagian kulit kering \\
16. & A16 & Kulit sering mengalami jerawat \\
17. & A17 & Makeup sulit menempel di wajah \\
18. & A18 & Sering mengalami alergi di wajah saat memakai \\
19. & A19 & Kulit wajah iritasi \\
20. & A20 & Kulit wajah cepat memerah \\
21. & A21 & Pembuluh darah terlihat jelas di permukaan wajah \\
22. & A22 & Mengalami masalah jika menggunakan produk baru \\
23. & A23 & Memiliki permasalahan blackhead di wajah \\
24. & A24 & Ketika bangun tidur, wajah tampak mengkilap \\
25. & A25 & Kulit wajah berminyak setelah menggunakan facial \\
& & wash \\
26. & A26 & Saat memakai makeup, setelah beberapa waktu, \\
27. & A27 & Wakeup akan luntur di area T-Zone \\
28. & A28 & Wajah akan gatal jika terkena sinar matahari \\
29. & A29 & Kulit wajah mengalami luka bakar jika terpapar sinar \\
30. & A30 & Jika terkena sinar matahari kulit menggelap \\
31. & A31 & Kulit terasa kering setelah menggunakan facial wash \\
\hline & &
\end{tabular}

Tabel 5. Tabel Pemberian nilai NA Pasien

\begin{tabular}{|c|c|c|c|}
\hline Pasien & Kode & Tingkat Kenyakinan & Nilai CF \\
\hline \multirow{8}{*}{ Pasien 02} & $\mathrm{~A} 01$ & Sangat Yakin & 1.0 \\
\hline & $\mathrm{A} 02$ & Yakin & 0.8 \\
\hline & A03 & Tidak Yakin & 0.2 \\
\hline & $\mathrm{A} 04$ & Yakin & 0.8 \\
\hline & A05 & Yakin & 0.8 \\
\hline & A06 & Tidak Yakin & 0.2 \\
\hline & A11 & Sedikit Yakin & 0.4 \\
\hline & $\mathrm{A} 30$ & Cukup Yakin & 0.6 \\
\hline \multirow{8}{*}{ Pasien 04} & A07 & Yakin & 0.8 \\
\hline & A14 & Cukup Yakin & 0.6 \\
\hline & A 15 & Cukup Yakin & 0.6 \\
\hline & A16 & Sedikit Yakin & 0.4 \\
\hline & A17 & Yakin & 0.8 \\
\hline & A23 & Yakin & 0.8 \\
\hline & A 25 & Sedikit Yakin & 0.4 \\
\hline & A26 & Sedikit Yakin & 0.4 \\
\hline \multirow{9}{*}{ Pasien 06} & A09 & Yakin & 0.8 \\
\hline & A12 & Yakin & 0.8 \\
\hline & A18 & Cukup Yakin & 0.6 \\
\hline & A19 & Sedikit Yakin & 0.4 \\
\hline & $\mathrm{A} 20$ & Yakin & 0.8 \\
\hline & $\mathrm{A} 21$ & Tidak Yakin & 0.2 \\
\hline & A22 & Yakin & 0.8 \\
\hline & $\mathrm{A} 28$ & Yakin & 0.8 \\
\hline & A 29 & Sangat Yakin & 1.0 \\
\hline
\end{tabular}

Setelah meninjau semua aturan yang dipilih oleh pengguna, proses perhitungan menggunakan aturan pertama, karena semua aturan yang ada, aturan pertama telah terpenuhi. Kemudian langkah selanjutnya berdasarkan aturan pertama adalah proses perhitungan menggunakan metode faktor kepastian sesuai Rule 4 yang hasilnya disajikan pada Tabel 6 .

Rule 4 = IF [A07:0.6] AND [A14:0.8] AND [A15:0.8] AND [A16:0.4] AND [A17:0.8] AND [A23:0.8] AND [A25: 0.6] AND [A26:0.6] THEN K4 
Tabel 6. Estimasi Certainty Factor Sekuensial dari Data Pasien 04

\begin{tabular}{cccc}
\hline Kode & CF Pakar & CF User & Hasil \\
\hline A07 & 0.6 & 0.8 & 0.48 \\
A14 & 0.8 & 0.6 & 0.48 \\
A15 & 0.8 & 0.6 & 0.48 \\
A16 & 0.4 & 0.4 & 0.16 \\
A17 & 0.8 & 0.8 & 0.64 \\
A23 & 0.8 & 0.8 & 0.64 \\
A25 & 0.6 & 0.4 & 0.24 \\
A26 & 0.6 & 0.4 & 0.24 \\
\hline
\end{tabular}

Setelah mendapatkan hasil $\mathrm{CF}$, maka adalah menghitung nilai $\mathrm{CF}$ bergabung menggunakan Persamaan (2). Penggabungan ini dilakukan karena memiliki lebih dari 1 indikasi. HAsil penggabungan disajikan pada Tabel 7.

Tabel 7. Estimasi Certainty Factor Sekuensial dari Data Pasien 04

\begin{tabular}{cc}
\hline Hasil & CF Gabungan $=\mathrm{NA}_{1}+\mathrm{NA}_{2} *\left(1-\mathrm{NA}_{1}\right)$ \\
\hline $\mathrm{Ke}-1$ & $0.48+0.48 *(1-0.48)=0.7296$ \\
$\mathrm{Ke}-2$ & $0.7296+0.48 *(1-0.7296)=0.8593$ \\
$\mathrm{Ke}-3$ & $0.8593+0.16 *(1-0.8593)=0.8818$ \\
$\mathrm{Ke}-4$ & $0.8818+0.64 *(1-0.8818)=0.9574$ \\
$\mathrm{Ke}-5$ & $0.9574+0.64 *(1-0.9574)=0.9846$ \\
$\mathrm{Ke}-6$ & $0.9846+0.24 *(1-0.9846)=0.9882$ \\
$\mathrm{Ke}-7$ & $0.9982+0.24 *(1-0.9982)=0.9912$ \\
\hline Hasil & $0.9912 * 100 \%=99.12 \%$ \\
\hline
\end{tabular}

Hasil CF terakhir merupakan gabungan hasil diagnosa yang menentukan jenis kulit wajah menggunakan perhitungan Certainty Factor dan karena terpenuhinya aturan pertama menggunakan teknik Forward Chaining maka hasil diagnosa dari data pasien 04 menyatakan bahwa pengguna memiliki jenis kulit wajah kombinasi dengan tingkat kepercayaan 99,12\%.

\subsection{Validasi}

Penelitian ini bertujuan untuk menganalisis jenis kulit wajah pada manusia. 30 sampel data digunakan untuk melakukan pengujian sistem, 30 data tersebut merupakan data pasien pada objek penelitian. Tingkat akurasi yang diperoleh dalam sistem dapat dicari dengan menggunakan Persamaan (3).

Tingkat Akurasi $=\frac{\text { Jumlah data benar }}{\text { Jumlah data uji }} \times 100 \%$

Hasil validasi yang dilakukan terhadap 30 sample data terdapat 5 yang tidak valid. Maka htingkat akurasinya adalah:

Tingkat Akurasi $=\frac{25}{30} \times 100 \%=83.33 \%$

Setelah didapatkan akurasi data dengan menggunakan persamaan (3), akurasi pada Sistem Pakar menentukan jenis kulit wajah pada manusia sebessar $83.33 \%$ dengan perhitungan Certainty Factor.

\subsection{Hasil}

Dari hasil pengolahan 5 contoh data menggunakan metode Certainty Factor, dapat dilihat pada Tabel 8.
Tabel 8. Tabel Pengolahan 5 Data Pasien

\begin{tabular}{cccc}
\hline $\begin{array}{c}\text { Nama } \\
\text { Pasien }\end{array}$ & $\begin{array}{c}\text { Kode } \\
\text { Penyakit }\end{array}$ & Nama Penyakit & Nilai CF \\
\hline Pasien 02 & K2 & Kulit Berminyak & $99.66 \%$ \\
Pasien 04 & K4 & Kulit Kombinasi & $99.12 \%$ \\
Pasien 06 & K5 & Kulit Sensitif & $99.89 \%$ \\
Pasien 08 & K1 & Kulit Normal & $99.25 \%$ \\
Pasien 10 & K3 & Kulit Kering & $98.99 \%$ \\
\hline
\end{tabular}

Hasil Sistem Pakar dapat diakses dengan menggunakan perangkat lunak yaitu Mozila Firefox. Di mana tampilan Sistem Pakar menentukan Jenis Kulit Wajah pada Manusia dapat dilihat pada Gambar 2:

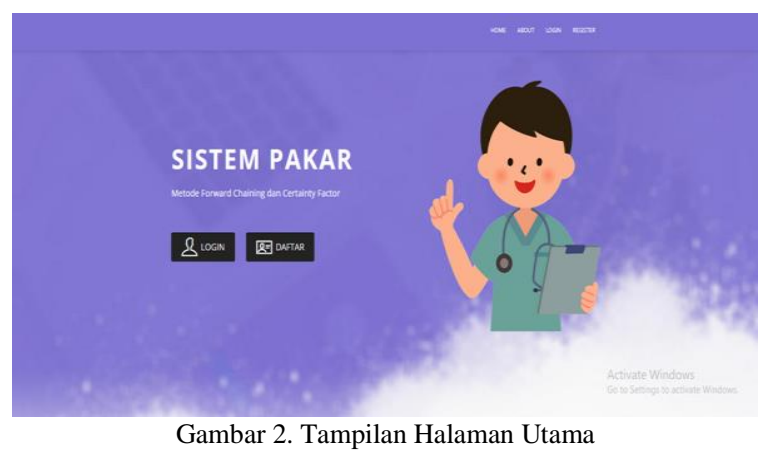

Sistem Pakar dibuat dengan tampilan yang sangat sederhana, bertujuan untuk dapat mempermudah User dalam menggunakannya. User hanya perlu mendaftar untuk dapat mengakses halaman konsultasi. Halaman konsultasi sistem disajikan pada Gambar 3:

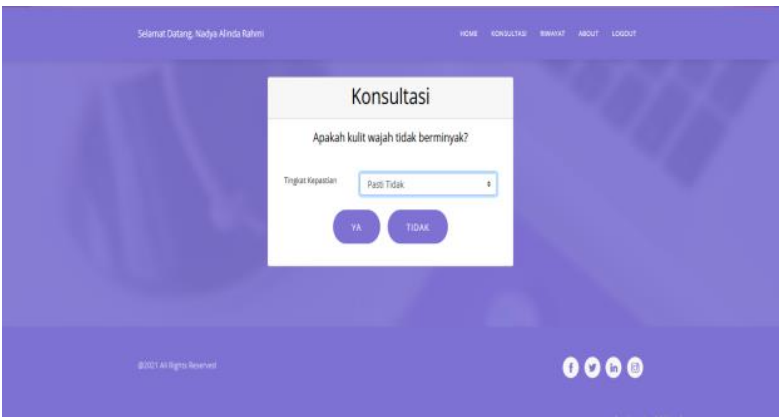

Gambar 3. Tampilan Halaman Konsultasi

Pada halaman konsultasi User memilih nilai CF yang dirasakan oleh User setelah selesai memilih nilai $\mathrm{CF}$ User dapat langsung menekan tombol cek konsultasi. Sistem akan menampilkan hasil diagnosa berdasarkan gejala yang telah dipilih oleh pengguna. Tampilan hasil konsultasi disajikan pada Gambar 4:

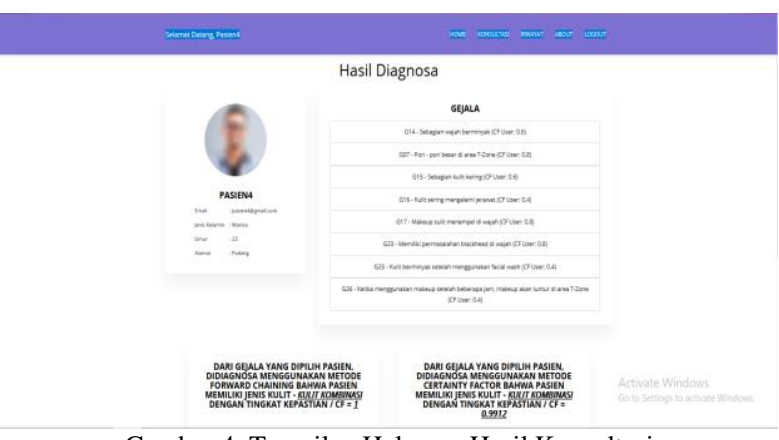

Gambar 4. Tampilan Halaman Hasil Konsultasi

Jurnal Sistem Informasi dan Teknologi Vol. 3 No. 4 (2021) 257-262 
Pada halaman hasil konsultasi bisa dilihat bahwa User dapat mengoperasikan program dengan memasukkan gejala dan mendapatkan hasil diagnosa yakni User memiliki jenis kulit kombinasi dengan tingkat kenyakinan sebesar $99.12 \%$.

\section{Kesimpulan}

Sistem Pakar dalam menganalisis jenis kulit wajah pada manusia telah berhasil diimplementasikan dengan menguji 31 gejala dan 5 jenis kulit wajah. Pengujian validasi sistem juga telah dilakukan dengan menggunakan 30 data sebagai sampel untuk pengujian dengan tingkat akurasi $83.33 \%$.

\section{Daftar Rujukan}

[1] Goralski, M. A., \& Tan, T. K. (2020). Artificial intelligence and sustainable development. The International Journal of Management $\quad$ Education, 180330. https://doi.org/10.1016/j.ijme.2019.100330

[2] Arfajsyah, H. S., Permana, I., \& Salisah, F. N. (2018). Sistem Pakar berbasis android untuk diagnosa penyakit gigi dan mulut. Jurnal Ilmiah Rekayasa dan Manajemen Sistem Informasi, 4(2), 110-117. http://dx.doi.org/10.24014/rmsi.v4i2.5678

[3] D.Dhivya, A., \& Felix, A. (2018). A Fuzzy Rule based Expert System for T2DM Diagnosis. International Journal of

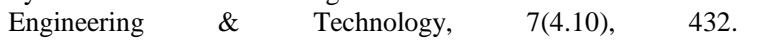
https://doi.org/10.14419/ijet.v7i4.10.21034

[4] Tashmetov, T., Tashmetov, K., Aliev, R., \& Rasulmuhamedov, M. (2020). Fuzzy information and expert systems for analysis of failure of automatic and telemechanic systems on railway transport. Chemical Technology, Control and Management, 2020(5), 168-172. https://doi.org/10.34920/2020.5-6.168-171

[5] Yuhandri, Y. (2018). Diagnosa Penyakit Osteoporosis Menggunakan Metode Certainty Factor. Jurnal RESTI (Rekayasa Sistem Dan Teknologi Informasi), 2(1), 422-429. https://doi.org/10.29207/resti.v2i1.349

[6] Sihombing, A., \& Sarjono, S. (2021). Analisis Dan Perancangan Sistem Pakar Untuk Mendiagnosa Penyakit Vertigo Dengan Metode Dempster Shafer. Jurnal Manajemen Sistem Informasi,
$6(1)$,

43-54. https://doi.org/10.33998/jurnalmanajemensisteminformasi.2021. 6.1 .1002

[7] Gracia, B., Setiabudi, D. H., \& Andjarwirawan, J. (2021). Sistem Pakar Diagnosa Kerusakan Pada Gitar Menggunakan Metode Forward Chaining dan Certainty Factor. Jurnal Infra, 9(1), 52-58.

[8] Hao, X., Wen, C., Zhao, N., Lu, L., Zhang, K., \& Zhang, D. (2020). Prototype of an Expert System for the Selection of Aircraft Structural Materials. International Journal of Photoenergy, 2020 1-7. https://doi.org/10.1016/j.jmatprotec.2005.04.034

9] Fakhriyah, N. N. (2021). Sistem Pakar Diagnosis Penyakit Pada Kambing Dengan Metode Forward Chaining Dan Certainty Factor. Jurnal Teknologi Informasi, Komputer, dan Aplikasinya (JTIKA), 3(1), 72-84. https://doi.org/10.29303/jtika.v3i1.138

[10] Salman, F. M., \& Abu-Naser, S. S. (2020). Expert System for COVID-19 Diagnosis.

11] Chandra, S., Yunus, Y., \& Sumijan, S. (2020). Sistem Pakar Menggunakan Metode Certainty Factor untuk Estetika Kulit Wanita dalam Menjaga Kesehatan. Jurnal Informasi dan Teknologi, 105-111. https://doi.org/10.37034/jidt.v2i4.70

[12] Santi, I. H., \& Andari, B. (2019). Sistem Pakar Untuk Mengidentifikasi Jenis Kulit Wajah dengan Metode Certainty Factor. INTENSIF: Jurnal Ilmiah Penelitian dan Penerapan Teknologi Sistem Informasi, 3(2), 159-177. https://doi.org/10.29407/intensif.v3i2.12792

[13] Romli, I., Romansyah, E., \& Permana, A. (2020). Implementasi Sistem Pakar menggunakan Metode Certainty Factor Untuk Mendiagnosa Penyakit Herpes Zoster. Jurnal JTIK (Jurnal Teknologi Informasi dan Komunikasi), 4(2), 110-115. https://doi.org/10.35870/jtik.v4i2.158

[14] Gultom, Z. H. (2018). Sistem Pakar Untuk Mendeteksi Kerusakan Pada Sepeda Motor Dengan Menggunakan Metode Forward Chaining Berbasis Web. Digital Zone: Jurnal Teknologi Informasi dan Komunikasi, 9(1), 42-58. https://doi.org/10.31849/digitalzone.v9i1.1075

[15] Safira, L., Si, S., \& Irawan, M. B. (2019). Implementation of the Certainty Factor Method for Early Detection of Cirrhosis Based on Android. In Journal of Physics: Conference Series (Vol. 1201, No. 1, p. 012053). IOP Publishing. http://doi:10.1088/1742-6596/1201/1/012053 